\title{
A Network-Based Peer Evaluation Strategy
}

\author{
Mohamed A. Alket \\ Assistant Professor, College of Science and Arts in Alrass, Qassim University, KSA \\ Email: medolink@gmail.com
}

\begin{abstract}
The purpose of this study was to design a network-based peer evaluation strategy -which included two types of peer evaluation (known and unknown) to investigate the effect of these two types on developing problem-solving and critical thinking skills for students in Java object oriented programming language course (OOP). The participants of this study were twenty-four $(n=24)$ students at College of Science and Arts, Qassim university. The results revealed that the two types of peer evaluation (in both known and unknown) had a positive effect on developing problem-solving and critical thinking skills for students. After, the comparison between the post-application of the two experimental groups in the problem solving and critical thinking skills, although there is a slightly higher between mean ranks in the sake of the unknown group, the results showed that there were no significant differences between the two groups. Finally, the researcher recommended to using a network-based peer evaluation strategy with other specializations and a large sample.
\end{abstract}

Index Terms-Peer evaluation, problem-solving skills, object-oriented programming, and critical thinking.

\section{INTRODUCTION}

Evaluation processes are affected by the ICT, as is the case in the educational process as a whole. Moreover, new variables appeared that affect the evaluation process in terms of the form and style of presentation, content material, ways and means used, as well as the environment in which evaluation processes occur. This was associated with all that is new in the technological world including the Internet, social networking, educational content management systems and cloud computing. Other innovations in technology impact the world all the time. Thus, they come to affect the provision of tools and patterns that one should invest in a systematic and orderly education. Hence, the evaluation process has evolved to improve judgment on what students know and what they can do and to become effective learning tools. One such process is peer evaluation [18]. As mentioned in [34] peer evaluation is a process in which learners evaluate the performance or achievement of peers. Although this concept is more general, many researchers clarified it in more detail such as [49]who defined peer evaluation as a type of motivating students, consists of students' discussions and providing instance feedback on other students' works.
Therefore peer evaluation has been used in more than form, but the majority was used in two forms (summative evaluation and formative evaluation). The summative evaluation used to judge the performance of students at the end of the course or module, while formative evaluation is used for learning. It is targeted in this study as this form which provides effective participation opportunities and collaborative work among the learners. It also allows good learning opportunities for student participation in teaching each other. Hence, it contributes to more understanding, self-appreciation, developing critical and creative thinking, thus enhancing the ability to motivate learners. A student plays in this form the role of an assessor for each other's work and is assessed by other peers; therefore they should present constructive feedback on their peer's works and receive responses.

From the aforementioned, it may be deduced that peer evaluation presents learning features which can be summarised in the following:

- Engaging learners to enhance deeper thinking and to interact with multiple learning resources [11].

- Improving students' skills in problem-solving by learning from the mistakes and innovations of peers [19].

- Requiring critical thinking by students; thus enhancing the ability to motivate students [46].

- Giving students some control and responsibility [13].

- Encouraging students to take an active role in managing their own learning [49].

- Improving the high-order thinking and learning motivation of students [56].

- Acquiring cognitive for assessors and assesses. [41].

In addition to features of peer evaluation, a networkbased evaluation (internet, intranet) adds many advantages for activating the role of the learners. More broadly, it depends on network properties. Some features that can be obtained from a network-based peer evaluation can be illustrated in the following:

- Presenting direct and immediate feedback on other students' works.

- Presenting many types of feedback.

- Using multimedia in feedback (text- image animation - audio).

- Providing interaction and discussion among peers.

- Showing a list of enrolled peers online. 
- Recording discussion sessions to show them another time.

- Providing coloring feedback and responses of different colors for each learner.

Therefore, a lot of learning processes adopted using a network-based peer evaluation [55].

Even though peer evaluation has many advantages, many studies mentioned that it emphasizes the quality of peer evaluation for each other faithfully and fairly without courtesy, favor or concerns associated [58, 54]. Therefore, it is an important issue to study the following independent variables: (known peer evaluation and unknown Peer evaluation).

In this study, the known type is defined as "students that show their data (the name, Id) on the network for others during peer evaluation processes", and the unknown type is on the opposite, those whose data is hidden from each other (anonymous).

In this study, two experimental groups of students were used to determine the effect of two independent variables on the following dependent variables: (problem-solving skills and critical thinking skills).

Those variables will be implemented In Java object oriented programming language course (OOP) in the computer-science department at Qassim University, in a review of previous literature; the researcher found that many studies have addressed the issue of using electronic peer evaluation as follows:

Numerous studies highlighted the comparison between self and peer evaluation and showed the advantages and disadvantages of each type, hence they pinpointed how to use these two types of learning processes and to develop the abilities of students $[10,31,21,22]$. There seems to be a consensus that online peer evaluation enriches the learning processes for the students, and that cooperative work encourages students to play an interactive role in their learning as well as in enhancing the ability to motivate students to acquire skills.

On other hand, there are many studies focusing on peer evaluation within the electronic environment and its related variables. [43], for example, used peer evaluation and feedback strategy to enhance the effectiveness of learning computer programming. The result showed that the students were satisfied with the peer evaluation and feedback strategy in learning computer programming. Moreover, the actual performance was also better when compared with that achieved using conventional teaching methods.

[1] developed an online peer assessment system to evaluate team-level feedback. Findings emphasized that using a computer system improves the efficiency of administering formative peer assessments and improves the quality of feedback and the changes in team behavior.

Following in the same footstep, [8] also stated the importance of peer evaluation to enhance student's problem-solving skills as illustrated in the result.

[36] Investigated peer observation and feedback on students' learning. They determined that peer assessment was helpful to students, especially later in the course timeline. An important finding from their work was that students became better at peer assessment after practice.

[48] examined two interaction types (synchronous and asynchronous) in peer feedback strategy within an electronic learning environment to identify their impact on achievement, motivation, and attitudes. Findings revealed that presenting peer feedback in asynchronous type was more effective than the use of the other type, the reason is due to the use of direct and immediate feedback which was not available in the asynchronous type, so the researcher strongly emphasized the importance to use synchronous type to present peer feedback.

[53] examined 114 undergraduate, to investigate the effectiveness of peer assessment in a professionalism course using an online workshop. Findings indicated that students were consistent in scoring the assignments as compared with one another, and they were consistent with the professor's ratings on the same assignment.

[57] conducted a motivation model of peer assessment in a university-level $\mathrm{C}$ programming course, because he believes that a fundamental problem in peer assessment is that participants lack the motivation to assess others' work faithfully and fairly. Results showed that students got a feeling of achievement and conducted peer assessment more carefully and actively.

\section{PROBLEM STATEMENT}

From the aforementioned, it may be deduced that although literature contained several relevant studies, no studies investigated the impact of two types (known, unknown) within network- based peer evaluation on the following dependent variables: (problem-solving skills, and Critical thinking skills), wherefore the current research adopted to design a networks-based peer evaluation strategy which includes steps and actual procedures for measuring the impacts of independent variables on the dependent variables, hence we can determine that the research problem lies in that a lot of computer-science students suffer from the difficulty of understanding the programming courses in general, and object-oriented programming in particular. Moreover, some students avoid the use of these programming languages in graduation projects. The case is so, the researcher ventured into designing the proposed strategy which provides good educational opportunities for the participation of students in teaching each other, thus contributing to greater understanding and development of critical thinking and problem-solving types of support. So we can determine the aims of this study as answering the following questions:

The main question of the study can be posed as follows:-

"What is a network-based peer evaluation strategy?"

Accordingly, the following sub-questions can be asked:

1. What is the effect of (known, unknown) peerevaluation type within the proposed strategy on developing problem-solving skills? 
2. What is the effect of (known, unknown) peerevaluation type within the proposed strategy on developing critical thinking skills for students?

\section{RELATED WORK}

\section{A. (Known, Unknown) Peer Evaluation}

There are many variants of peer evaluation. The basic aim of this strategy is to involve students in the evaluation process providing their peers with the feedback on the quality of their work. In some cases, the practice of peer evaluation includes the assigning of a grade as it is widely recognized and fraught with difficulties [50].

Regardless that peer evaluation process will include the assigning of a grade or not, it should be in the context of specific and accurate criteria. These criteria are not only for students but also include all electronic learning environments. A web-based system such as learning management systems (LMS) plays a huge role in a peer evaluation process as it presents many tools and properties that help students and teachers. Because of the important role of using the web-based system in the learning process, the researcher - in the current studyadopted (Blackboard system) as an official e-learning system at Qassim University. [52] showed the philosophical foundation upon peer evaluation strategy. He said that this system can support the interaction among the students and between the instructors and students.

Peer evaluation is well-accepted as good and effective sources of performance evaluation for students. In order to ensure that the students' feedback towards their classmates devoid of the courtesy and favoritism, the student's identities of the experimental group will not appear online when they start peer evaluation process. So the benefit of the electronic environment (the desired interaction among students) will be achieved. There are many studies adopted this strategy.

[32] developed a mobile-based peer evaluation system to assess students' works of computer curriculum in an elementary school. The aim of that study was to investigate the user perception toward that system. The results were positive towards using mobile based peer evaluation system.

Also, [3] described the impact of electronic peer evaluation system on 389 undergraduate business students. They were evaluated by their peers; the system allows to receive unknown feedback, the findings indicated that the students' perceptions through their peers increased more.

Moreover, [30] focused on the attitudes of computer science students toward Web-based peer assessment. They used NetPeas as the interactive channel and the system to implement two-way anonymous peer assessment.

\section{B. Problem-Solving and Critical Thinking Skills}

The most effective learnings are those problems and activities that immerse the learner in the situation that require him to acquire skills in order to solve the problem; therefore one of the important goals of education is to help students learn to use what they have learned to solve problems in new situations [40]. Hence problem-solving is defined as a cognitive process includes logical steps to find a solution to a problem [14, 17].

According to [40], problem-solving is cognitive processing which concerned with achieving a goal when no solution is obvious to the problem solver.

In order to improve students' performance in learning specifically computer programming and also improve their abilities in problem-solving. Network-based peer evaluation provides online learning environment requires cooperation and interaction, hence allows discussion and reflection which students defines problems in a collaborative way of working, suggesting solutions and deciding the appropriate solution with each other[5]. The problem-solving process consists of a set of steps includes problem definition, problem analysis, problem synthesis and suggested solutions [26].

The first stage of the problem-solving cycle is understood the problem, hence introduce the accurate analysis of the problem in the second stage and come to the step of synthesis and apply after that in order use the information gathering previously to generate multiple solutions. Undoubtedly that thinking plays a vital role in all previous stages starting with understanding the problem to generate solutions; wherefore Nagang has stated that thinking is the ability to cope with the problem and generate the solutions by intelligently and rational [42]. As mentioned in $[14,17]$ that thinking starts with a problem. Additionally that developing the ability and skills for students to become good thinkers will foster their abilities to problem-solving.

Critical thinking is a form of a thinking helps to make the right decisions after reviewing the information and data that is collected as it undergoes tests of rational and logical, in preparation for sentencing. As for the 'critical' word, it means careful and accurate evaluation [12]. There are many tries to define the concept critical thinking in the educational and psychological domain which started with Dewey (1933,p.118) described critical thinking as "active persistent and careful consideration of a belief or supposed form of knowledge in light of the grounds that support it, and the further conclusions to which it tends." Recent years, critical thinking is defined as the ability to think and to refrain from judgment before making any decision [20]. Additionally [2] mentioned that critical thinking term refers to the importance of using of cognitive skills or strategies that lead to desirable outcomes. Hence it is the type of thinking contributes in problem-solving and making decisions [25].

On another hand, many studies also point out that critical thinking requires higher cognitive skills which include creativity, evaluation, and analysis [28, 16].

From the aforementioned, it may be deduced the importance of the role of critical thinking which is a vital type of thinking helps to problems solving, those skills 
requires development within the framework of a cooperative, participatory, interactive and meaningful in specific standards context, thus the current study intends to design a networks-based peer evaluation strategy which provides suitable learning environment for acquisition of previous skills.

\section{A Network-Based Peer Evaluation Strategy}

Applying successful learning strategies in an electronic learning environment should be collaborative and interactive. They should allow the discussion and reflection to gain more understanding about this strategy.

There are some procedures and recommendations can be showed by the previous literature review. In the current study, the researcher adopts design a networksbased peer evaluation strategy. This strategy is based on two factors: (a) peer feedback type and (b) peer interaction type.

The first factor, according to [48] peer feedback is the process of discussions among learners which associated with their performance during the learning process. It provides unique chances to present a good performance to learners in collaborative and interactive context. Also, peer feedback is based on the active role which helps the learners to manage their learning [35].

Moreover, peer feedback promotes the learning process as it specifies the points of weakness and strengths for learners. It helps them to receive new ideas for developing their performance [38].

Many studies pointed out that usefulness and benefits of peer feedback were not less than teacher feedback [39, $24,4$,$] . In order to ensure that the peer feedback provided$ in a good context, learners must take training on how to provide feedback and comments towards their classmates' work. On the other hand, with regard to the types of peer feedback, there are a set of peer feedback types based on the learners as it was mentioned in [37] as following:
1. Description: It includes notes and comments only without giving approval or rejection.

2. Simple Judgment: Judgment without explanation to this view and the reason behind it.

3. Elaborated Judgment: Judgment includes either rejection or acceptance with an explanation for this opinion and the reason behind it.

4. Suggestion: addition to the previous points provides, it should be appropriate proposals for peers.

The researcher strongly emphasizes the view that peer feedback should include suggestions type which includes judgment with interpretation and explained reasons, especially with the presence of some of the studies which underscored the lack of confidence among some learners with regard to assistance from the peers [4].

The Second factor, feedback timely is the important factor in the success peer evaluation process. The majority of the studies indicated that feedback should be timely $[29,47,7]$ since one of the factors that lead to the weakness of the feedback is presented to the learners too late. If it is provided timely, immediately, frequented and linked to what is expected of the learner's performance, it will motivate students to improve their learning, provide students with performance improvement data, correct errors, build confidence among the students and identify strengths and weaknesses [44]. For this, the design of the proposed strategy depends on that providing feedback among peers will be synchronous and in a specific time.

According to the factors preceding and the properties of the target sample, java programming course and electronic environment, the researcher designed a networks-based peer evaluation strategy as shown in the next figure.

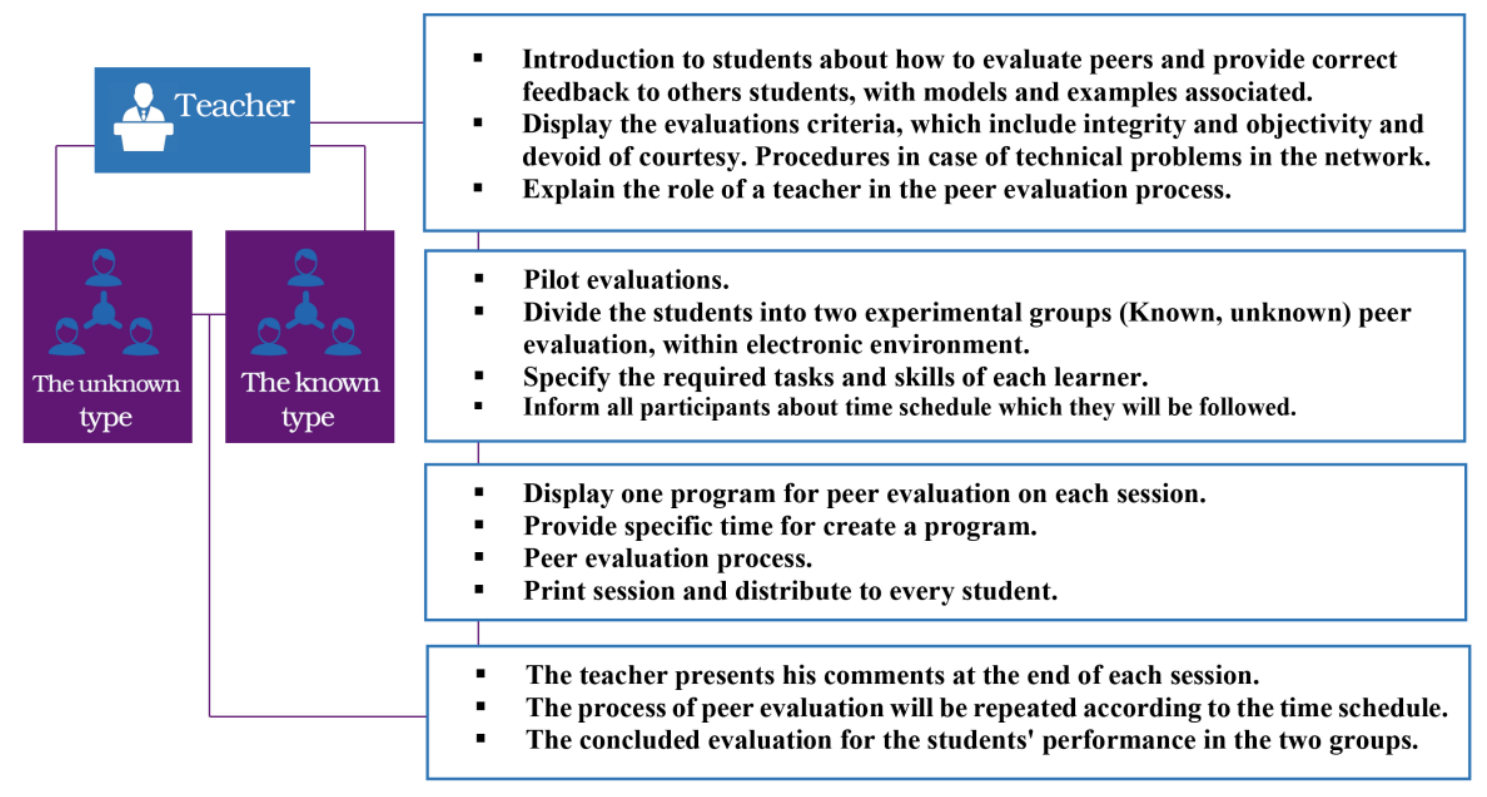

Fig.1. A Suggested networks-based peer evaluation strategy 


\section{METHOD}

The current study was conducted in Java object oriented programming language course (OOP), Department of Computer Science, faculty of sciences and arts, Qassim university, K.S.A. The participants were from level 5 and 6 in the department of computer and sciences. The main purpose of this study was to design a network-based peer evaluation strategy which includes two types of peer evaluation (known and unknown) and to investigate the effect of these two types on developing problem-solving and critical thinking skills for students.

\section{Context and procedures:-}

To prepare students for participation in this study, the researcher give introduction to the students about how to evaluate peers and provide correct feedback to others students with models and examples associated and display the evaluations criteria, which include integrity and objectivity and devoid of courtesy and favoritism, as well as explain the role of a teacher in the peer evaluation process and what the procedures in case of technical problems in the network.

The next step was to train students how to evaluate experimentally peer with actual models. Consequently, the students distributed for two experimental groups (Known, unknown) peer evaluation, within an electronic environment, each group include twelve students with specifying the required tasks and skills of each learner.

During ten weeks provides to students the Java object oriented programming language course through two lectures every week, every lecture contains one session include one program to evaluate peer at each session, thus providing a specific time to create a program followed peer evaluation process. At the end of each session, the teacher provides discussion with students and give them all comments and observations.

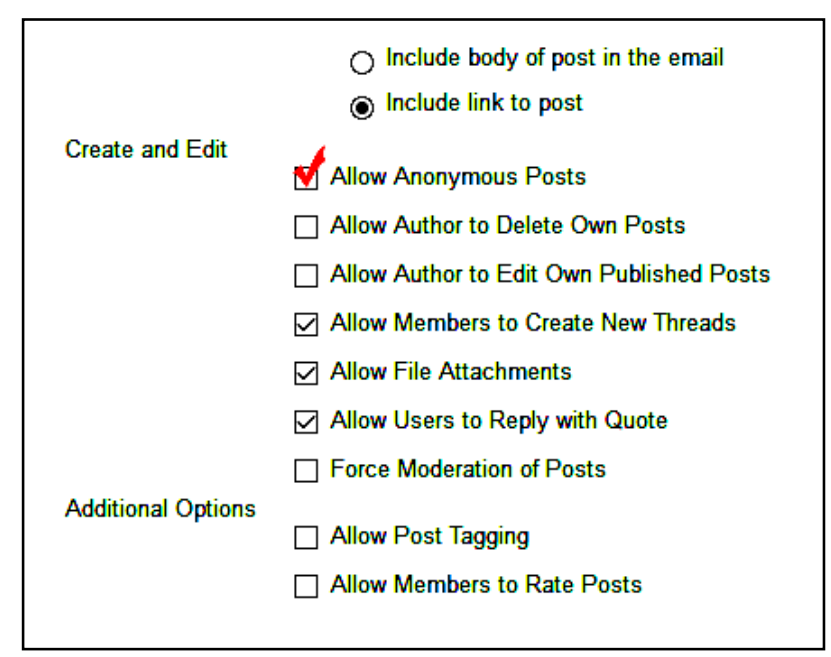

Fig.2. Blackboard (LMS) Option for allowing Anonymous posts

\section{Participants:-}

The sample of the study consisted of twenty-four students $(n=24)$ who were selected, excluding the students who participated in the pilot study to measure the validity and reliability of the study instruments.

\section{Instruments of the study:-}

The author developed the student's problem-solving skills test (observation list), based on a rubric, adopted from [23], which included four main parts as following:

The first part was: problem representation, which consisted of two constructs: identifying the causes of the problem and identifying relevant information. The second part was: developing solutions, which consisted of two constructs: developing solutions and quality of solutions. The third part was solutions justification: which consisted of two constructs: constructing arguments and providing evidence. Finally, the fourth part was evaluating solutions. All constructs were measured on ( 4 points) from $(0=$ No solution, $1=$ weak, $2=$ good, $3=$ excellent $)$. An example available at appendix 1 .

The content validity of the problem-solving skills test was conducted by the pilot study included three of computer science members and three graduate students. These members modified some items to help me to obtain an accurate score.

Reliability coefficient was calculated using the Cronbach's alpha equation by using SPSS statistical analysis software, it obtained by two groups of students $(n=24)$. The Cronbach's alpha coefficient calculated for all parts (seven constructs) as $(0.74,0.86,0.70,0.88,0.64$ 0.88 , and 0.82 , respectively). The constancy of coefficient (0.862), it is generally agreed, suggesting that the test on the acceptable degree of stability.

For measuring the critical thinking skills, the author developed the measure questionnaire based on Uf-EMI [27] and similar studies that adopted this to measure the critical thinking skills of students [33, 51].The measurement included twenty-five items under three parts, the first part includes eleven items to measure engagements construct (engagement with object oriented programming), the second part contains eight items to measure cognitive maturity, the third part includes six items to measure innovativeness. Appendix2.

All items were measured on 5 points scales (from 1= strongly disagree to 5 strongly agree), also the content validity of the critical thinking skills questionnaire was conducted by the pilot study included three of computer science member and three graduate students. The researcher modified some items according to the suggestions that obtained from the member and the students. Also, reliability coefficient was calculated using the Cronbach's alpha equation, the Cronbach's alpha coefficient calculated for all items between $(0.54-0.85)$, it considered agreed, suggesting that the test on the acceptable degree of stability.

\section{Limitations of the study:-}

The study had the following limitations:-

- Spatial Limitations: The Faculty of Sciences and Arts, Qassim University, K.S.A. 
- Java object oriented programming language course (OOP), Department of Computer Science.

- Time Limitations: The second term of the academic year 2015/2016.

- Human Limitations: Students in Level 5 and 6 in the Dep't. Of computer sciences.

- There are a small number of participants was used, so it difficult to generalize the results. Thus this study can only be regarded as a case study.

\section{Methodology of the study:-}

The current study used the quasi-experimental design methodology. The design comprised the following variables:

A- The independent variable :( Known Peer evaluation and Unknown Peer evaluation).

B- The dependent variables :( Problem Solving and Critical thinking Skills).

\section{RESUlts}

For answer the research questions, the researcher used descriptive statistical analysis. The first question asked if there was an effect of (known, unknown) peer-evaluation type within the proposed strategy on developing problemsolving skills. To examine if there are initial differences between the pre and post application for each single group, used Wilcoxon Signed Ranks Test with alpha set at (0.05). To compare between the two groups in the postapplication, Mann-Whitney Ranks Test was used.

Table 1. Shows the difference in the mean ranks between the pre and post application of the problem-solving skills in the (Known type) group using Wilcoxon Signed Ranks Test.

\begin{tabular}{|c|c|c|c|c|c|}
\hline $\begin{array}{c}\text { Problem- } \\
\text { Solving } \\
\text { Skills }\end{array}$ & $\mathbf{N}$ & Mean Rank & $\begin{array}{c}\text { Sum of } \\
\text { Ranks }\end{array}$ & $\mathbf{Z}$ & Sig \\
\hline $\begin{array}{c}\text { Negative } \\
\text { Ranks }\end{array}$ & 1 & 2.50 & 2.50 & -2.867 & .005 \\
\hline $\begin{array}{c}\text { Positive } \\
\text { Ranks }\end{array}$ & 11 & 6.86 & 75.50 & & \\
\hline
\end{tabular}

As it is shown in the previous table, there are significant differences between mean ranks in the problem-solving skills for the sake of the post application, where $\mathrm{Z}$ value (-2.812) with significance level at (.005). This results refers to the presence of a marked improvement in problem-solving skills for students of the first experimental group (known type) after exposure to a network-Based peer evaluation strategy.
Table 2. Shows the difference in the mean ranks between the pre and post application of the problem-solving skills in the (Unknown type) group using Wilcoxon Signed Ranks Test.

\begin{tabular}{|c|c|c|c|c|c|}
\hline $\begin{array}{c}\text { Problem- } \\
\text { Solving } \\
\text { Skills }\end{array}$ & $\mathbf{N}$ & Mean Rank & $\begin{array}{c}\text { Sum of } \\
\text { Ranks }\end{array}$ & $\mathbf{Z}$ & Sig \\
\cline { 1 - 4 } $\begin{array}{c}\text { Negative } \\
\text { Ranks }\end{array}$ & 0 & .00 & .00 & -2.823 & .005 \\
\cline { 1 - 3 } $\begin{array}{c}\text { Positive } \\
\text { Ranks }\end{array}$ & 10 & 5.50 & 55.00 & & \\
\cline { 1 - 3 } Ties & 2 & & & & \\
\hline
\end{tabular}

As it is shown in the previous table, there are significant differences between mean ranks in the problem-solving skills for the sake of the post application, where $\mathrm{Z}$ value $(-2.823)$ with significance level at (.005). This results refers to the presence of a marked improvement in problem-solving skills for students of the second experimental group (unknown type) after exposure to a network-Based peer evaluation strategy.

Table 3. Shows the results using Mann-Whitney Ranks Test to measure the mean ranks in the problem-solving skills between the postapplication of the study instruments between the two experimental groups (known, unknown).

\begin{tabular}{|c|c|c|c|c|c|c|}
\hline & $\begin{array}{c}\text { Mean } \\
\text { Rank }\end{array}$ & $\begin{array}{c}\text { Sum of } \\
\text { Ranks }\end{array}$ & U & W & Z & Sig \\
\hline G1 & 12.08 & 145.00 & \multirow{2}{*}{67.000} & 145.000 & -.289 & .77 \\
\hline G2 & 12.92 & 155.00 & & & \\
\hline
\end{tabular}

The result showed that there is no significance in the problem-solving skills between the post-application of both the two experimental groups, where $U(12)=67.000$, $\mathrm{Z}=-.289, \mathrm{p}>.05, \mathrm{r}=.77$. Hence after the two types were exposed to a network-based peer evaluation strategy in Java object oriented programming language course, the results showed that there was no a priority of significance for a type more than the other in developing the skill of programming problem solving for the students of computer science department.

From the above explanation, the researcher can answer the first question: What is the effect of (known, unknown) peer-evaluation type within the proposed strategy on developing problem-solving skills?

As there was a positive effect and a remarkable improvement for the students' level of computer science department when the two experimental groups were exposed to a network-based peer evaluation strategy in Java object oriented programming language course. Also, there was no a priority of significance for a type more than the other in developing the skill of programming problem solving for the students after they were exposed to the suggested strategy. 
The second question asked if there are the effect of (known, unknown) peer-evaluation type within the proposed strategy on developing Critical thinking skills.

To examine if there are differences between the pre and post application for each single group, used Wilcoxon Signed Ranks Test with alpha set at (0.05). To compare between the post-application between the two groups Mann-Whitney Ranks Test was used.

Table 4. Shows the difference in the mean ranks between the pre and post application of the critical thinking skills in the (Known type) group using Wilcoxon Signed Ranks Test.

\begin{tabular}{|c|c|c|c|c|c|}
\hline $\begin{array}{c}\text { Critical } \\
\text { thinking } \\
\text { Skills }\end{array}$ & $\mathbf{N}$ & Mean Rank & $\begin{array}{c}\text { Sum of } \\
\text { Ranks }\end{array}$ & $\mathbf{Z}$ & Sig \\
\hline $\begin{array}{c}\text { Negative } \\
\text { Ranks }\end{array}$ & 0 & .00 & .00 & - & .002 \\
\hline $\begin{array}{c}\text { Positive } \\
\text { Ranks }\end{array}$ & 12 & 6.50 & 78.00 & & \\
\hline
\end{tabular}

As it is shown in the previous table, there are significant differences between mean ranks in the Critical thinking skills for the sake of the post application, where $\mathrm{Z}$ value (-3.061) with significance level at (0.02). This results refers to the presence of a marked improvement in critical thinking skills for students of the first experimental group (known type) after exposure to a network-Based peer evaluation strategy.

Table 5. Shows the difference in the mean ranks between the pre and post application of the critical thinking skills in the (Unknown type) group using Wilcoxon Signed Ranks Test.

\begin{tabular}{|c|c|c|c|c|c|}
\hline $\begin{array}{c}\text { Critical } \\
\text { thinking } \\
\text { Skills }\end{array}$ & $\mathbf{N}$ & Mean Rank & $\begin{array}{c}\text { Sum of } \\
\text { Ranks }\end{array}$ & $\mathbf{Z}$ & Sig \\
\cline { 1 - 4 } $\begin{array}{c}\text { Negative } \\
\text { Ranks }\end{array}$ & 0 & .00 & .00 & - & .003 \\
\cline { 1 - 3 } $\begin{array}{c}\text { Positive } \\
\text { Ranks }\end{array}$ & 11 & 6.00 & 66.00 & 2.936 & \\
\hline Ties & 1 & & & & \\
\hline
\end{tabular}

As it is shown in the previous table, there are significant differences between the mean ranks in the Critical thinking skills for the sake of the post application, where $\mathrm{Z}$ value (-2.639) with significance level at (0.03). This results refers to the presence of a marked improvement in critical thinking skills for students of the second experimental group (unknown type) after exposure to a network-Based peer evaluation strategy.

Table 6. Shows the result using Mann-Whitney Ranks Test to measure the mean ranks in the Critical thinking skills between the postapplication of the study instruments between the two experimental groups (known, unknown).

\begin{tabular}{|c|c|c|c|c|c|c|}
\hline & $\begin{array}{c}\text { Mean } \\
\text { Rank }\end{array}$ & $\begin{array}{c}\text { Sum of } \\
\text { Ranks }\end{array}$ & U & W & Z & Sig \\
\hline G1 & 11.92 & 143.00 & \multirow{2}{*}{65.000} & 143.000 & -.405 & .685 \\
\hline G2 & 13.08 & 157.00 & 65.00 & & &
\end{tabular}

The result showed that there is no significance in the Critical thinking skills between the post-application of both the two experimental groups, where $U(12)=65.000$, $\mathrm{Z}=-.405, \mathrm{p}>.05, \mathrm{r}=.685$. Hence after the two types were exposed to a network-based peer evaluation strategy in Java object oriented programming language course , the results showed that there was no a priority of significance for a type more than the other in developing the skill of programming critical thinking for the students of computer science department.

From the above explanation, the researcher can answer the second question: What is the effect of (known, unknown) peer-evaluation type within the proposed strategy on developing critical thinking skills for students?

As there was a positive effect and a remarkable improvement for the students' level of computer science department when the two experimental groups were exposed to a network-based peer evaluation strategy in Java object oriented programming language course. Also, there was no a priority of significance for a type more than the other in developing the skill of critical thinking for the students after they were exposed to the suggested strategy.

\section{DISCUSSION AND CONCLUSIONS}

This study aimed to design a network-based peer evaluation strategy, which included two types of peer evaluation (known and unknown), and investigate the effect of these two types on developing problem-solving and critical thinking skills for students in Java object oriented programming language course (OOP).

The results of the current study demonstrated that the problem-solving skills scale mean ranks in the pre and post an application in the first group (known), were significantly greater for the sake of the post application, also for the second group (unknown) they were significantly greater for the sake of the post application.

These results indicated that a suggested peer evaluation strategy plays a vital role in the learning process as it provides the students with effective participation opportunities and collaborative work. These results agree with [43]. Also, in this strategy, the student plays as an assessor for other students' work and vice versa. Moreover, the suggested network-based peer evaluation strategy provides the students with a lot of problems and activities that immerse them in the learning situation so the students can acquire skills in order to solve the problems. These results agree with [5], who investigated the effect of two online peer assessment roles (assessor and assessee) on students' performance in problemsolving skills. The results showed that there were many problem-solving skills improved and an increasing resident students' in solving problems logically.

According to the comparison in the post-application for both the two experimental groups in the problem-solving skills, the results showed that although there was a slightly higher between mean ranks in the sake of the unknown group, there were no significant. This was probably because of the small sample size. So it is 
recommended to use a large sample size in similar future research.

Critical thinking skills scale mean ranks in the pre and post were significantly greater for the sake of the post application for the two groups (known and unknown). Undoubtedly, the application of successful learning strategies in an electronic learning environment should be based on collaborative and interactive activities, discussion and reflection to lead to desirable outcomes specifically with regard to improve the thinking skills of students. In this context, the current study adopted to design a networks-based peer evaluation strategy based on providing the peers with immediately feedback about form inclusive judgment with interpretation and explain the reasons synchronously. Therefore, it motivates students to improve their learning, provides them with performance improvement data, corrects errors, grows the confidence in the students and identifies strengths and weaknesses. This elevates the ability of students' critical thinking and this result agrees with [44, 11].

Lastly, although there is a slightly higher between mean ranks in the sake of the unknown group, there was no significance in the Critical thinking skills between both of the two experimental groups in the postapplication. This also probably dues to the small sample size.

Finally, the researcher held Simi organized interviews after the end of treatment with the two groups' students about their impressions of a network- based peer evaluation environment, the results of the interviews were as the following:

Appendix 1 List of assessing student's problem-solving skills:

\begin{tabular}{|c|c|c|c|c|c|}
\hline Parts & Constructs & No solution(0) & Weak(1) & $\operatorname{Good}(2)$ & Excellent(3) \\
\hline \multirow[t]{2}{*}{$\begin{array}{c}\text { Problem } \\
\text { representation }\end{array}$} & $\begin{array}{l}\text { identifying the } \\
\text { causes of the } \\
\text { problem }\end{array}$ & $\begin{array}{l}\text { no logic reason of } \\
\text { the problem }\end{array}$ & $\begin{array}{l}\text { Present the causes } \\
\text { of the problem }\end{array}$ & $\begin{array}{l}\text { display the causes of } \\
\text { the problem and } \\
\text { examined }\end{array}$ & $\begin{array}{l}\text { display multiple causes of the } \\
\text { current problem and examined }\end{array}$ \\
\hline & $\begin{array}{l}\text { identifying relevant } \\
\text { information }\end{array}$ & $\begin{array}{l}\text { No known the } \\
\text { factors and } \\
\text { constraints }\end{array}$ & $\begin{array}{l}\text { identify the factors } \\
\text { or constraints }\end{array}$ & $\begin{array}{l}\text { identify the factors and } \\
\text { constraints }\end{array}$ & $\begin{array}{l}\text { identify the factors and } \\
\text { constraints in many cases }\end{array}$ \\
\hline \multirow[t]{2}{*}{$\begin{array}{l}\text { Developing } \\
\text { solutions }\end{array}$} & $\begin{array}{l}\text { developing } \\
\text { solutions }\end{array}$ & $\begin{array}{l}\text { No solution is } \\
\text { developed }\end{array}$ & $\begin{array}{l}\text { the solution is } \\
\text { developed but } \\
\text { without } \\
\text { explanations about } \\
\text { how they work }\end{array}$ & $\begin{array}{l}\text { the solution is } \\
\text { developed with poor } \\
\text { explanations about } \\
\text { how they work }\end{array}$ & $\begin{array}{l}\text { the solution is developed with } \\
\text { accurate explanations about how } \\
\text { they work }\end{array}$ \\
\hline & $\begin{array}{l}\text { the quality of } \\
\text { solutions }\end{array}$ & $\begin{array}{l}\text { No solution has } \\
\text { been suggested }\end{array}$ & $\begin{array}{l}\text { provide a weak } \\
\text { solution }\end{array}$ & $\begin{array}{l}\text { provide a good } \\
\text { solution }\end{array}$ & provide an excellent solution \\
\hline \multirow[t]{2}{*}{$\begin{array}{c}\text { Solutions } \\
\text { justification }\end{array}$} & $\begin{array}{l}\text { constructing } \\
\text { arguments }\end{array}$ & $\begin{array}{l}\text { No arguments are } \\
\text { constructed }\end{array}$ & $\begin{array}{l}\text { Arguments is } \\
\text { poorly }\end{array}$ & Arguments is good & Arguments is strong \\
\hline & providing evidence & $\begin{array}{l}\text { No evidence } \\
\text { available }\end{array}$ & Evidence is weak & $\begin{array}{l}\text { Evidence to support } \\
\text { the arguments is good }\end{array}$ & $\begin{array}{l}\text { Evidence to support the } \\
\text { arguments is strong }\end{array}$ \\
\hline $\begin{array}{c}\text { Evaluating } \\
\text { solutions }\end{array}$ & & $\begin{array}{l}\text { The solutions is } \\
\text { not evaluated }\end{array}$ & $\begin{array}{l}\text { Evaluation of the } \\
\text { solution is stated } \\
\text { but no constraints } \\
\text { are mentioned }\end{array}$ & $\begin{array}{l}\text { The proposed solution } \\
\text { is evaluated } \\
\text { and the constraints are } \\
\text { mentioned but without } \\
\text { explanation }\end{array}$ & $\begin{array}{l}\text { The solution is evaluated and the } \\
\text { constraints are mentioned with } \\
\text { an explanation about how } \\
\text { constraints can be eliminated }\end{array}$ \\
\hline
\end{tabular}

Appendix 2 The questionnaire of critical thinking skills:

\begin{tabular}{|c|c|}
\hline Main parts & Items \\
\hline \multirow{11}{*}{$\begin{array}{c}\text { Engagement with object oriented } \\
\text { programming }\end{array}$} & I am a good problem solver. \\
\hline & I like finding solutions to challenge questions. \\
\hline & I have the ability to treat with some issue together. \\
\hline & I have the ability to explain things clearly. \\
\hline & I have the ability to use my skills in a variety of issues. \\
\hline & I have the ability to present issues in a clear way. \\
\hline & I can reach to a responsible conclusion. \\
\hline & I am interested in many issues related with oop. \\
\hline & I like problems that raise my thinking. \\
\hline & I ask specific questions when I try to clarify solutions. \\
\hline & You should be well informed of the problem. \\
\hline \multirow{8}{*}{ Cognitive maturity } & I am a good listener to others, even if they differ with me. \\
\hline & I try to discuss ideas to reach to ideal solutions. \\
\hline & I ask many questions related to the problem before making a decision. \\
\hline & I avoid the personal bias before making decisions. \\
\hline & I try to find multiple solutions for each problem. \\
\hline & I respect the persons who they disagree with me in my opinion. \\
\hline & I am ready to change my opinion when I get new information about the problem. \\
\hline & I believe that there are many solutions for each problem. \\
\hline \multirow[t]{6}{*}{ Innovativeness } & I ask lots of questions to reach a clear vision. \\
\hline & I try to analysis the solutions before I discuss with others. \\
\hline & I enjoy with solving problems. \\
\hline & I enjoy with identifying multiple solutions for one problem. \\
\hline & I like the discussion with others to reach the appropriate solutions to the problems. \\
\hline & I like to listen carefully to others when they discuss solutions.. \\
\hline
\end{tabular}


The first item was about immediate feedback that students receive from their peers. One of the students' comments was "Correct the programming errors from my colleagues helped me to understand the course content". The second item was about providing students with the opportunity of playing the role of the teacher as assessor to others. One of the students' comments was "I was very happy and excited to help my colleagues to correct their mistakes as it motivated me to strive than ever". The third point was about the collaborative work among the students. One of the students' comments was "it was really a helpful chance to have time to discuss the problem solution with my colleagues".

\section{ACKNOWLEDGMENT}

The author (Mohamed A. Alket) gratefully acknowledge Qassim University, represented by the Deanship of Scientific Research, on the material support for this research under the number (3403) during the academic year $1436 \mathrm{H} / 2015 \mathrm{AD}$.

\section{REFERENCES}

[1] Anson, R., \& Goodman, J. (2014). A Peer Assessment System to Improve Student Team Experiences, journal of education for business, 89: 27-34.

[2] Bie, H., Wilhelm, P., \& Meij, H. (2015). The Halpern critical thinking assessment: toward a Dutch appraisal of critical thinking, thinking skills and creativity 17(2015)3344.

[3] Brutus, S., \& Donia, M. (2010). Improving the effectiveness of Students in Groups with a Centralized Peer Evaluation System, Academy of Management Learning \& Education, 2010, Vol. 9, No. 4, 652-662.

[4] Cardella, M., Diefes-Dux, H., Verleger, M., Fry, A., \& Carnes, M. (2011). Work in Progress - Using Multiple Methods to Investigate the Role of Feedback in OpenEnded Activities, 41st ASEE/IEEE Frontiers in Education Conference, Pages: S4D-1 - S4D-3, DOI: 10.1109/FIE.2011.6143106 October 12 - 15, 2011, Rapid City, SD.

[5] Cevik, Y. (2015). Assessor or assessee? Investigating the deferential effects of online peer assessment roles in the development of students' problem-solving skills, computer in humans behavior, 52(2015)250-258.

[6] Cevik, Y., Haslaman, T., \& Celik, S. (2015). The effects of peer assessment on problem solving skills of prospective teachers supported by online learning activities, students in educational evaluations, 44(2015) 23-35.

[7] Chan Koh, L. (2008). Refocusing formative feedback to enhance learning in pre-registration nurse education, Nurse Education in Practice (2008) 8, 223-230. Retrieved from: www.elsevier.com/nepr.

[8] Chang, S., Chah yu, L., Kuo, Y., Mai, Y., \& Dechen, J. (2015). Applying online peer assessment with total quality management to elevate project-based learning performance, journal of Baltic Science education, Vol. 14, No. 3, (P. 379-390).

[9] Chen Chuang, W. (2009). The effects of four different types of corrective feedback on EFL students' writing in Taiwan, Da-Yeh journal of general education, P 123-138.

[10] Chengqing Wu., Chanda, E., \& Willison, J. (2014). Implementation and outcomes of online self and peer assessment on group based honors research projects,
Assessment \& Evaluation in Higher Education, Vol. 39, No.1, 21-37.

[11] Chiu-Lin Lai, Hawang, J. (2014). A peer-assessment criteria development approach to improving critical thinking of students, 2014 IIAI 3rd International Conference on Advanced Applied Informatics. Retrieved from: http://ieeexplore.ieee.org/document/6913324/

[12] Cranney, J., \& Dunn, D. (2011). The psychologically literate citizen: Foundation and global perspectives, Oxford University press, ISBN-13:978-0-19-979494-2, BF77.P758.2011, New York.

[13] Cvetkovic, D. (2013). Evaluation of FCS Self and PeerAssessment Approach Based on Cooperative and Engineering Design Learning, 35th Annual International Conference of the IEEE EMBS Osaka, Japan, 3 - 7 July, 2013, 978-1-4577-0216-7/13/\$26.00 @2013 IEEE.

[14] Demirel, M., \& Derman, I., \& Karagedik, E. (2015). A study on the relationship between reflective thinking skills towards problem-solving attitudes towards mathematics, procedia - Social and behavioral sciences 197(2015) 20862096.

[15] Dewey, J. (1933) How to think, New York: D. C, Health \& Co publishers.

[16] Dilley, A., et al. (2012). What we know about critical thinking, p21partenarshiop for $21^{\text {st }}$-century learning. Retrieved from http://www.p21.org

[17] Dusek, G., \& Ayhan, A. (2014). A study on problemsolving skills of the children from broken family and full parents family attending regional primary boarding school, procedia - Social and behavioral sciences 152(2014) 137142.

[18] Dziedzic, M., Janissek, P., \& Bender, A.(2008).Assessment by Peers - An Effective Learning Technique, 38th ASEE/IEEE Frontiers in Education Conference, October $22-25,2008$, Saratoga Springs, ny.

[19] El-Mowafy, A. (2014) Using peer assessment of fieldwork to enhance students' practical training, assessment \& evaluation in higher education, Vol. 39, No.2, 223-241.

[20] Facione, P. (2011). Critical thinking: What it is and why it counts, insight assessment, Measured Reasons and The California Academic Press, Millbrae, CA.

[21] Fermelis, j., Tucker, R., \& Plamer, S. (2007). Online self and peer assessment in large, multi-campus, multi-cohort contexts, Proceedings ascilite Singapore, 271-281. Retrieved from: http://www.ascilite.org/conferences/singapore07/procs/fer melis.pdf.

[22] Gaytan, J., \& McEwen, B. (2007). Effective Online Instructional and Assessment Strategies, the American journal of distance education, 21(3), 117-132.

[23] Ge, X., \& Land, S. M. (2003). Scaffolding student's problem-solving processes in an ill-structured task using question prompt and peer interaction. Educational technology research and development, 51(1), 21-38.

[24] Gielen, S., Tops, L., Dochy, F., Onghena, P., \& Smeets, S. (2010). A comparative study of peer and teacher feedback and of various peer feedback forms in a secondary school writing curriculum, British Educational Research Journal, Vol. 36, No. 1, February 2010, pp. 143-162.

[25] Halpern, D. (2003). Teaching for critical thinking: Helping College students develop the skills and disposition of a critical thinker, Jossey- Pass publishers.

[26] Hassan, S., Yusof, K., Mohammad, S., Abu, M., \& Tasir, Z. (2012). Methods to study enhancement of problem-solving skills in engineering students throw cooperative ProblemBased learning, the international conference on teaching and learning in higher education (ICTLHE 2012), procedia 
Social and behavioral Sciences 56(2012)737-746.

[27] Iran, T., et al. (2007) Critical thinking instrumentation manual. Gainesville, University of Florida.

[28] Jeevanantham, S. (2005). Why teach critical thinking? Africa education review, 2(1):188-129 doi: 10.1080/18146620508566295.

[29] Jiehong, W., Fuixang, G.(2009).Study of Feedback Teaching for Computer Culture Basics, Proceedings of 2009 4th International Conference on Computer Science \& Education. Retrieved from: http://ieeexplore.ieee.org/document/5228273/

[30] Jul in, S., Feng Liu, E., \& Ming-yuan, S. (2001). Webbased peer assessment: Does attitude influence Achievement? IEEE transactions on education, vol. 44, No 2, May 2001.

[31] Kearney, S. (2013). Improving engagement: the use of 'Authentic self- and peer assessment for learning' to enhance the student learning experience, Assessment \& Evaluation in Higher Education, Vol. 38, No. 7, 875-891. Retrieved from: http://dx.doi.org/10.1080/02602938.2012.751963.

[32] Lai, A., \& Chen, C. (2013). Mobile-Based peer assessment app and elementary students' perception: project works of computer curriculum as an example, 2013 EEE $13^{\text {th }}$ international conference on advanced learning technologies. Retrieved from: http://ieeexplore.ieee.org/document/6601999/

[33] Lamm, A., Harder, A., Irani, T., Roberts, T., \& Snyder, L. (2011). Developing strong international agricultural education programs by understanding cognition, Journal international of agricultural and extension education, 18(2), 30-39.

[34] LAN Li, Liu, X., \& Steckelperg, A. (2010). Assessor or assesse: How student learning improves giving and receiving peer feedback, British Journal of Educational Technology of 41 No 32010 525-536. Retrieved from: http://onlinelibrary.wiley.com/doi/10.1111/j.14678535.2009.00968.x/full.

[35] Liu, N., \& Carless, D. (2006).Peer feedback: the learning element of peer assessment, Teaching in Higher Education, Vol. 11, No. 3, July 2006, pp. 279-290. Retrieved from: http://www.tandfonline.com/doi/abs/10.1080/13562510600 680582.

[36] Liu, Z., Lee, C. (2013). Using peer feedback to improve learning via online peer assessment. Turkish Online Journal of Educational Technology, 12(1), 187-199.

[37] Liu, Z., \& Lin, S. (2007). The relationship between peer feedback, cognitive and meta cognitive strategies and achievement in networked peer assessment, British Journal of Educational Technology, Vol 38 No 6 2007. P 1122 1125.

[38] Lu, J., Law, N. (2012). Online peer assessment: effects of cognitive and affective feedback, Springer, Instr Sci (2012) 40:257-275. Retrieved from: http://link.springer.com/article/10.1007\%2Fs11251-0119177-2.

[39] Maarof, N., Yamat, H., Li li, K. (2011). The role of Teacher, Peer and Teacher-Peer Feedback in Enhancing ESL Students' Writing, World Applied Sciences Journal 15 (Innovation and Pedagogy for Lifelong Learning): 2935 .

[40] Mayer, R., \& Wittrock, M. (2006). Problem-solving, in P.A Alexander \& P.H winne(Eds), handbook of education psychology. Rutledge, 287-304.

[41] Mocozet, L.,Tardy, C. (2015). An assessment for learning framework with peer Assessment of group works, 978-1-
4799-1756-3. Retrieved

from: https://www.researchgate.net.

[42] Nagang, T., Nair, S., \& Prachak, B. (2013). Developing instruments to measure thinking skills and problem-solving skills among Malaysian primary school pupils, $5^{\text {th }}$ world conference on educational sciences - WCES , 116(2014)3760-3764.

[43] Ng, W. (2012). The Impact of Peer Assessment and Feedback Strategy in Learning Computer Programming in Higher Education, Issues in Informing Science and Information Technology, Volume 9.

[44] O'Farrell, C. (2007). Enhancing Student Learning through Assessment, a Toolkit Approach. Retrieved from http://learningandteaching.dit.ie/documents/assessment_to olkit_v41f.pdf

[45] Pearce, J., Mulder, R., \& Baik, C. (2009). Involving students in peer review Case studies and practical strategies for university teaching, Centre for the Study of Higher Education the University of Melbourne. Retrieved from http://www.cshe.unimelb.edu.au/

[46] Peggy, A.Ertmer. Richardson, J., Belland, B., Camin, D., Connoly, D., Coulthard, J., \& Mong, C. (2007). Using Peer Feedback to Enhance the Quality of student Online Postings: An Exploratory Study, Journal of computerMediated Communication, Volume 12, Issue 2, pages 412 433.

[47] Ran, J., Han, H., \& Wang, D. (2010). I Tutor: Taking formative assessment and interactive feedback as teaching and learning strategies for improving students' skill learning effectiveness, South China Normal University, Guangzhou, China.

[48] Shemy, N. (2015). Two interaction types (synchronize and asynchronous) in peer feedback strategy within electronic learning environment and its impact on the achievement, motivation and the trend towards, 4th - International Conference For e-learning \& Distance Education,2-5 march 2015. Retrieved from: http://eli.elc.edu.sa/2015.

[49] Sitthiworachart, J., et al. (2008). Computer support of effective peer assessment in an undergraduate programming class. Journal of computer assisted learning. Volume 24 (number 3). Pp. 217-231. ISSN 0266-4909.

[50] Spiller, D. (2012). Assessment Matters: Self-Assessment and Peer Assessment, Teaching Development Unit Wāhanga Whakapakari Ako, the university of Waikato. Retrieved from www.waikato.ac.nz/tdu.

[51] Stedman, N. L., \& Andenoro, C. (2007). Identification of relationship between emotional intelligence and critical thinking dispositions in undergraduate leadership students, journal of leadership education, 6(1), 190-208.

[52] Steven D, Lonn. (2009). Student use of a learning management system for group projects: a case study investigating interaction, collaborative, and knowledge construction, a dissertation submitted in partial fulfillment of the requirements for the degree of doctor of philosophy, university of Michigan, Retrieved from https://deepblue.lib.umich.edu/bitstream/handle/2027.42/6 4743/slonn_1.pdf.

[53] Strang, K. D. (2015). The effectiveness of peer assessment in a professionalism course using an online workshop. Journal of Information Technology Education: Innovations in Practice, 14, 1-16. Retrieved from http://www.jite.org/documents/Vol14/JITEv14IIPp001016Strang0350.pdf

[54] Trahasch, S. (2004). Towards a Flexible Peer Assessment System, German Research Foundation DOI: 10.1109/ITHET.2004.1358227 
[55] Uto, M., \& Ueno, M. (2015). Item Response Theory for Peer Assessment, IEEE transactions on learning technologies, Volume 9, Issue 2, p 157-170.

[56] Wang, Y. (2008). E-Portfolios: A New Peer Assessment Technology in Educational Context, International Symposiums on Information Processing, IEEE computer society, P 360-363. DOI 10.1109/ISIP.2008.139.

[57] Wang, Y., Liang, Y., Liu, L., \& Liu, Y. (2014). A Motivation Model of Peer Assessment in Programming Language Learning, computer and society. Retrieved from https://arxiv.org/abs/1401.6113

[58] Wavear, D., \& Esposto, E. (2012). Peer assessment as a method of improving student engagement, Assessment \& Evaluation in Higher Education, Vol. 37, No. 7, November 2012, 805-816.

\section{Authors' Profiles}

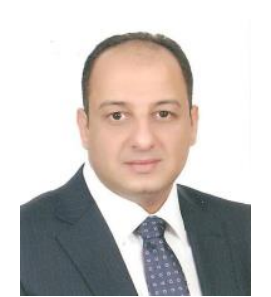

Dr. Mohamed A. Alket received his Ph.D Degree from Cairo University, Egypt. He is specialized in the use of computer and technology in education. He works as an assistant professor at Computer Science Dept., College of Science and Arts, Qassim University, Kingdom of Saudi Arabia. He has more than 10 years of experience in teaching, research and developing computer applications, in the field of e-learning distance education, Mobile learning, and information technology.

How to cite this paper: Mohamed A. Alket,"A Network-Based Peer Evaluation Strategy", International Journal of Modern Education and Computer Science(IJMECS), Vol.9, No.4, pp.32-42, 2017.DOI: 10.5815/ijmecs.2017.04.04 